\title{
Economic effect of short (35-d) compared with conventional (60-d) dry period management in commercial Canadian Holstein herds
}

\author{
D. E. Santschi, ${ }^{\star} \dagger^{1,2}$ D. M. Lefebvre, $\ddagger$ R. I. Cue,§ C. L. Girard, ${ }^{*}$ and D. Pellerin $†$ \\ *Agriculture and Agri-Food Canada, Dairy and Swine Research and Development Centre, Sherbrooke, Quebec, Canada, J1M 1 Z3 \\ †Département de Sciences Animales, Université Laval, Quebec, Canada, G1V 0A6 \\ $\ddagger$ Valacta, Ste-Anne-de-Bellevue, Quebec, Canada, H9X 3R4 \\ §Department of Animal Science, McGill University, Ste-Anne-de-Bellevue, Quebec, Canada, H9X 3V9
}

\begin{abstract}
The Canadian dairy industry operates under a supply management system with production quotas (expressed in kilograms of butterfat per day) owned by dairy producers. Any management strategy influencing production responses must, therefore, be evaluated to estimate its effects on quota needed to sell the milk produced. In the present study, half of the cows from 13 commercial herds (850 cows, average of 70 cows per herd) were assigned to be managed for a short dry period (SDP; $35 \mathrm{~d}$ dry) and the other half was managed for a conventional dry period (CDP; $60 \mathrm{~d}$ dry) to evaluate the economic impact of a steady state involving either CDP or SDP. Economic variables included in the partial budget were: variations in revenues from milk and components as well as animals sold; costs related to feeding, reproduction, replacement, housing, and treatments. All variables were first estimated on a cow basis for each herd individually, and average results were used to calculate the partial budget for an average herd. Yearly milk and component yields per cow increased, which implies that fewer cows are required to produce the same amount of quota. Accordingly, 2 scenarios were investigated: in the first one, available quota was kept constant, and herd size was adjusted to avoid over-quota production. Consequently, the partial budget was calculated considering that 5 fewer cows were present in the herd. In this situation, switching to an SDP management increased net annual income for the farm by $\$ 2,677$ (Can $\$$ ), which represents $\$ 41.38$ per cow. In the second scenario, the number of cows was kept constant, but additional quota $(5.5 \mathrm{~kg} / \mathrm{d}, \$ 25,000 /$ $\mathrm{kg}$ ) was bought to allow selling all of the milk produced. In this case, net farm income was increased by $\$ 17,132$ annually with SDP, which represents $\$ 245.18$ per cow.
\end{abstract}

\footnotetext{
Received July 5, 2010.

Accepted May 24, 2011.

${ }^{1}$ Current address: Valacta, Ste-Anne-de-Bellevue, Quebec, Canada,

${ }^{2}$ Corresponding author: dsantschi@valacta.com
} H9X 3R4.
This budget includes interest on the purchase of quota. A comparison of partial budgets for individual herds involved in the study revealed considerable variation among herds. Switching from a CDP to a SDP management would be beneficial for average dairy herds in eastern Canada.

Key words: short dry period management, economic impact, dairy cow

\section{INTRODUCTION}

It is general practice to allow dairy cows a dry period between lactations. Although this period has usually been 2 mo, many cows still produce large quantities of milk 60 d before calving, and are, therefore, difficult to dry-off. Cessation of milking imposes an important stress on the mammary gland, in addition to stress due to changes in ration and physiological changes in preparation for parturition. Recent studies have demonstrated that a shorter dry period (DP) of 35 d could be beneficial for these cows (Watters et al., 2008; Klusmeyer et al., 2009). This new management strategy would allow harvesting extra milk at the end of lactation, while giving enough time for regeneration of the udder (Capuco et al., 1997). In addition, the latest studies published suggest no negative effects on production in the following lactation (Watters et al., 2008, Klusmeyer et al., 2009). Moreover, this management practice would facilitate transition between dry period and lactation by improving energy status in early lactation cows (Rastani et al., 2005; Pezeshki et al., 2007; Jolicoeur et al., 2009). This management strategy could, therefore, decrease metabolic problems and improve reproduction (Watters et al., 2008; 2009).

All these factors are of economic importance to the producer. In addition, a short DP (SDP) management strategy involves different feeding programs than the conventional DP (CDP) management, which will likely result in variations in costs. However, studies looking at the effects of SDP have seldom considered the overall economic impact of this practice. Sørensen et al. (1993) used a stochastic stimulation model to estimate effects 
of various dry period lengths $(4,5,6,7,8,9$, or $10 \mathrm{wk})$ and 4 different management systems (combinations of high- or low-concentrate feeding and high or low culling rate). Their calculations were based on results from a previous experiment with 366 cows measuring the effects of various preplanned dry period lengths $(4,7$, and 10 wk) on production during the first 24 wk of the following lactation (Sørensen and Enevoldsen, 1991). Calculations included costs related to feeding and breeding of cows and heifers as well as revenues from milk and livestock sold. Results from this simulation study suggest that maximal net benefit would be obtained with a dry period of $7 \mathrm{wk}$ under the various combinations of feeding regimen and culling strategy studied. In a study involving 3 commercial herds, Annen et al. (2004) estimated that decreasing the dry period from 60 to $30 \mathrm{~d}$ would increase cumulative net margin at $17 \mathrm{wk}$ of the subsequent lactation by an additional $\$ 40$ per multiparous cow. In contrast, the economic effect was negative for primiparous cows by wk 17 of their second lactation. Cows used in their study were supplemented with $\mathrm{bST}$, the cost of which was included in the calculation. However, besides production responses, the authors did not consider other effects which could be of economic importance, such as reproduction and veterinary costs. In addition, calculations from their experiment focused on the first weeks following parturition, and did not extend to complete lactations.

The Canadian dairy industry operates under a supply management system, ensuring balance between milk production and consumer demand (Canadian Dairy Commission, 2010). This system guarantees stability of the domestic supply, and consequently prevents fluctuations in producer revenues from milk sold. Each producer owns several shares in this market (production quota) and is required to maintain production according to quota owned. Quota is expressed in kilograms of butterfat (BF) per day. Any management strategy influencing daily milk fat yield will, therefore, influence the amount of quota required. As a consequence, the producer must adjust to herd production level either by a quota transaction or by buying or selling cows. Producers receive no payment for over-quota production. In addition, the Canadian milk payment system is based on the quantity of each milk component sold (fat, protein, lactose, and other solids) rather than on the volume of milk produced (Canadian Dairy Commission, 2010).

To our knowledge, no study has measured the overall economic impact of short DP management under field conditions. The purpose of the present study was, therefore, to estimate the costs and benefits associated with SDP or CDP management for commercial Holstein herds from Quebec, Canada, to estimate overall profitability of this new management practice. Income factors included in the calculations were revenues from production (milk and component yields) as well as animals sold. Costs considered involved feeding, treatments and veterinary interventions, reproduction, replacement, and housing.

\section{MATERIALS AND METHODS}

All experimental procedures were approved by the Animal care committee from Université Laval, Quebec, Canada. All economic values are provided in Canadian dollars (Can\$; average for 2007-2008: 1 Can $\$=0.94$ US\$; Bank of Canada).

\section{Experimental Procedures}

Details of the experiment examining the effects of SDP or CDP on production, metabolic disorders, and reproduction were reported previously (Santschi et al., 2011a,b). This experiment was also designed to include estimation of the economic impact of these 2 management practices. Briefly, a total of 850 cows (414 primiparous and 436 multiparous) from 13 commercial Holstein herds from Quebec, Canada, were included in the study. Herd size ranged from 37 to 175 cows (median $=68$ cows). The average herd production level before the experiment was 10,198.9 $\pm 325.0 \mathrm{~kg}$ per lactation (mean $\pm \mathrm{SE}$ ), with lactation length average of $335.9 \pm 4.5 \mathrm{~d}$ (mean $\pm \mathrm{SE}$ ). Herds were mainly housed in tie-stall barns (11 out of 13) with the 2 remaining herds being in freestalls. Five farms were feeding TMR, whereas the other 8 farms had individual concentrate feeding systems. Cows from 1 herd were milked 3 times daily; all others were milked twice. All herds were requested to have monthly individual cow milk recordings for production and composition as well as an existing transition cow management strategy (including far-off and pre-calving rations) to join the study.

Every other month, cows in their sixth or seventh month of gestation within each herd were assigned to either a CDP (60-d) or a SDP (35-d) management strategy. Treatment groups were balanced for parity (primiparous vs. multiparous), previous 305-d milk yield and estimated calving interval. Cows in the CDP group were fed a far-off dry cow ration until $21 \mathrm{~d}$ before calving, and were then switched to a pre-calving ration. Cows in the SDP group received the pre-calving ration for the whole duration of their DP. All cows were fed the early lactation ration after calving. Rations were specific to each herd.

The method for drying-off was variable but key procedures were similar across herds: cows with low milk production were dried abruptly, whereas high-produc- 
ing cows were dried over several days, often with single daily milking to decrease production. All producers used dry cow antibiotics at dry-off, and were provided with SNAP Beta-Lactam Tests (Idexx Laboratories Inc., Westbrook, ME) to detect residues in early lactation milk.

Besides the ration change during the DP, producers were asked to feed and treat all cows as usual, and to report any noteworthy observation. The study lasted 2 yr, from January 2007 until December 2008. Each herd was visited every other week. All health and metabolic data were obtained either directly from the producer at each visit or through the veterinarian records. Definitions of metabolic disorders were given previously (Santschi et al., 2011b). Milk production response was also reported previously (Santschi et al., 2011a). Data on milk and component yields, times bred, as well as DIM at first breeding and at conception were obtained from Valacta (Dairy Production Centre of Expertise Quebec-Atlantic, Ste-Anne-de-Bellevue, QC, Canada). Information on reasons for, and DIM at culling was obtained from producers and Valacta.

\section{Economic Values and Calculations}

Effects of DP management on production, reproduction, and health have been previously reported (Santschi et al., 2011a,b). The same data set was used for the present economic study, but production, reproduction, and disease incidence measures were first computed on a herd basis, separately for first-, second-, and thirdand-greater-lactation cows. All measures were obtained for SDP and CDP cows separately.

Within each herd, the proportion of cows in each parity group was first determined. Then, actual milk and component yields were obtained for each parity group, as well as actual DP length and lactation length. These 2 parameters were used to estimate calving interval. All production responses were then expressed on a yearly basis (divided by calving interval and multiplied by 365 ), thus adjusting for the calving interval. This approach was necessary to obtain annual results and allow comparison among herds. Production data from culled cows was included in the calculations. Lactation and DP lengths were estimated from data of cows that completed lactation. Total lactation milk and component yields were then obtained through an estimate statement using the Mixed Procedure of SAS (version 9.2; SAS Institute, 2008), including monthly milk records from all cows.

The same approach was followed for all other variables of economic importance: number of breedings per conception, disease incidence, and culling rate. For calculation purposes, all variables were expressed per cow per year, to correct for herd size. The partial budget contrasting the 2 management strategies was then estimated from the average values of the 13 herds, based on the number of cows in respective proportions of first-, second-, and third-and-greater-lactation cows.

In an attempt to evaluate labor required by SDP and CDP management strategies, a questionnaire was distributed to the producers. They were asked to estimate time spent on various daily chores: ration preparation, feeding, milking, and group changes in the herd. Producers had to evaluate time required for each task for each group of cows according to lactation stage: early lactation, late lactation, dry, and pre-calving group. The same questionnaire also requested information on barn and stall sizes.

Table 1 summarizes the economic values used for calculations and provides reference to the source of these values. The quota price was set to $\$ 25,000 / \mathrm{kg}$ of $\mathrm{BF}$ per day (producers have to pay $\$ 25,000$ for the right to produce $1 \mathrm{~kg}$ of $\mathrm{BF} / \mathrm{d}$ ), which corresponds to the maximum price set for the province of Quebec in 2008 [Fédération des Producteurs de Lait du Québec (FPLQ), Longueuil, Quebec, Canada]. The interest on the quota bought was calculated as $8 \%$ over $10 \mathrm{yr}$. The average milk price value for 2008 was used for calculations: $\$ 9.57 / \mathrm{kg}$ of $\mathrm{BF}, \$ 8.20 / \mathrm{kg}$ of total milk protein, and $\$ 1.67 / \mathrm{kg}$ of lactose and other solids (FPLQ). Deductions on milk price (also average values for 2008) included transportation costs of $\$ 2.72 / 100 \mathrm{~L}$ of milk and marketing costs of $\$ 0.14 / \mathrm{kg}$ of milk solids. Breeding costs per service were estimated as the average cost of a semen dose (\$43.14) added to the cost of a visit from the AI technician (\$16.60). Housing costs were based on current construction costs reference values (CRAAQ, 2008). Other variable costs per cow included medications and veterinary treatments for other than metabolic diseases (vaccines, embryo transfers), direct costs for animals (bedding, registration), and short-term interest (reported on a cow basis per year; CRAAQ, 2005).

Estimates of costs related to the various disorders were obtained through veterinarians from the clinics involved in the present study (Table 2). Overall incidences of the various disorders according to DP management strategy used have been reported elsewhere (Santschi et al., 2011b). The veterinarians were asked to provide an estimate for each disease including several treatment options with or without veterinarian intervention. Metabolic disorders were then classified according to treatment used and an average cost was attributed to each class. For udder edema, only severe cases were considered because mild cases did not require treatment. Similarly, only severe cases of ketosis [milk Keto-Test (Elanco Animal Health, Guelph, ON, 
Table 1. Economic parameters used in the present analysis ${ }^{1}$

\begin{tabular}{ll}
\hline Item & $\begin{array}{l}\text { Economic } \\
\text { parameter }\end{array}$ \\
\hline Quota price $^{2}$ & $\$ 25,000.00 / \mathrm{kg}$ of BF \\
Milk price $^{3}$ & $\$ 9.57 / \mathrm{kg}$ \\
Fat & $\$ 8.20 / \mathrm{kg}$ \\
Protein & $\$ 1.67 / \mathrm{kg}$ \\
Lactose + other solids & $\$ 2.72 / \mathrm{hL}$ \\
Transportation costs & $\$ 0.14 / \mathrm{kg}$ of solids \\
Milk marketing costs & $\$ 59.74 / \mathrm{breeding}$ \\
Breeding costs & ${ }^{4}$ \\
Other variable costs per cow & $\$ 378.50 /$ cow per year \\
Replacement cost ${ }^{5}$ & $\$ 1,761.00 /$ heifer \\
Housing & $\$ 290.63 / \mathrm{m}^{2}$ \\
Value of animals sold & \\
Culled cow & $\$ 319.00 /$ cow \\
Female calf & $\$ 250.00 /$ calf \\
Male calf & $\$ 150.00 /$ calf
\end{tabular}

${ }^{1}$ All amounts are in Canadian dollars (Can\$).

${ }^{2}$ Quota price represents the right to produce $1 \mathrm{~kg}$ of $\mathrm{BF}$ daily. It was set to $\$ 25,000 / \mathrm{kg}$ of butterfat $(\mathrm{BF})$, which corresponds to the maximum price set for the province of Quebec in 2008. Source: Fédération des Producteurs de Lait du Québec (FPLQ), Longueuil, QC, Canada.

${ }^{3}$ Average values for 2008 obtained from FPLQ.

${ }^{4}$ Includes the visit of the AI technician $(\$ 16.60)$ and an average semen dose cost (\$43.14).

${ }^{5}$ Estimated from Agritel Web database (http://agritel.fgcaq.com/ Agritel), Fédération des groupes conseils agricoles du Québec (Longueuil, QC, Canada).

${ }^{6}$ CRAAQ (2008).

${ }^{7}$ Based on 2008 market prices.

Canada) result at or above $200 \mu \mathrm{mol}$ of $\mathrm{BHBA} / \mathrm{L}]$ were estimated because mild cases are generally not treated. Cases for milk fever were defined as mild (average of 2 doses of calcium required to treat the cow) or severe (several doses needed in addition to other medications, with occasional veterinarian intervention). Displaced abomasum included costs for the surgery and the veterinarian intervention as well as subsequent antibiotic treatment required. Only 2 cases of acute mastitis were reported throughout the project, and the cost associated with mastitis was, therefore, set to the cost of subacute cases; no veterinarian intervention necessary. Veterinary costs were computed as the costs (veterinarian fees + treatment costs) for each disease case multiplied by the incidence rate of the disease. The frequency of SNAP Beta-Lactam Test (Idexx Laboratories Inc.) usage was estimated in proportion to cows calving with less than $28 \mathrm{~d}$ dry in each herd. The cost of a SNAP Beta-Lactam Test was set to $\$ 2.93$, which corresponds to the individual cost per test when purchasing a box of 20 tests (Idexx Laboratories Inc.). The distribution of actual dry period lengths has been reported elsewhere (Santschi et al., 2011a).

Ration costs were obtained from each herd's nutritionist regularly throughout the experiment. Averaged ration costs were computed according to lactation stages, and feeding costs were estimated as the daily ration cost multiplied by the number of days this ration was consumed by each cow.

In all herds, dry cows were usually kept in the same building as the lactating cows (except summertime in some herds, when cows were outside). Stall space was calculated as the size of the building housing the cows (excluding all other rooms) divided by the number of stalls, to account for feed and alley space.

\section{Partial Budget}

All values were computed on a herd basis, and partial budgets were established for each herd accounting for the number of cows. Furthermore, average production, reproduction, and disease incidence results of the 13 herds were used to generate a partial budget for an average herd, representing the average of the 13 herds involved in the study. This average herd, therefore, had average production costs, and made average management decisions.

Because milk production in Canada is limited for each producer by the quota owned, 2 scenarios were investigated. In the first one, the amount of quota owned was maintained constant and the number of cows was, therefore, adjusted according to the amount of BF produced. In the second scenario, the number of cows was maintained constant, and additional quota was bought to allow shipping of the extra production (due to higher yearly production per cow with the SDP management strategy). Actual loss or benefit was then converted on a cow basis again, to allow comparison among herds.

\section{Statistical Analysis}

Statistical analysis was conducted on variables expressed on a cow basis for each herd using the MIXED procedure of SAS (version 9.2; SAS Institute, 2008). The model included the treatment (SDP or CDP) as

Table 2. Costs associated with metabolic disorders and diseases ${ }^{1}$

\begin{tabular}{lr}
\hline Disease & $\begin{array}{c}\text { Cost } \\
(\$ / \text { case })^{2}\end{array}$ \\
\hline Udder edema & 10.44 \\
Retained placenta & 4.71 \\
Metritis & 49.78 \\
Milk fever (mild) & 17.84 \\
Milk fever (severe) & 51.42 \\
Ketosis & 18.31 \\
Displaced abomasum & 160.27 \\
Mastitis & 22.22 \\
\hline
\end{tabular}

${ }^{1}$ All amounts are in Canadian dollars (Can\$).

${ }^{2}$ Costs include the price of medication as well as veterinary fees when required. 
fixed effect, with herd as random effect. Results were declared significant at $P \leq 0.05$.

\section{RESULTS AND DISCUSSION}

Demographic information on herds involved in the present study suggests that farms in this study are comparable to average Quebec dairy herds. The average proportion of first-, second-, and third-and-greaterlactation cows per herd was 38.4, 25.2, and 36.5\%, respectively. In comparison, the average proportion of third-or-greater-lactation cows in the province of Quebec was $41.0 \%$ in 2008 , with an average of 52.4 cows per herd (Valacta, 2009). Additional information on herds is presented in Table 3 .

\section{Economic Variables}

Comparison of SDP and CDP management strategies on parameters of economic importance are detailed in Table 4. Some values presented in this table slightly differ from values presented previously (Santschi et al., 2011a,b ) due to the fact that they are expressed on a yearly basis in the present case rather than on a lactation basis as in the previous papers.

The length of the DP was decreased $(P<0.001)$ for the SDP group, as expected. One economically important effect of the DP management strategy used was the decrease in calving interval associated with SDP (from 406 to $387 \pm 4 \mathrm{~d}$ for CDP and SDP, respectively; $P<0.001)$. The number of breedings per conception per cow per year was not different between DP management strategies $(P=0.82$; Table 4$)$.

Yearly milk and component yields per cow were increased with the SDP management $(P \leq 0.002)$. Veterinary services and replacement rates were similar for both management practices $(P \geq 0.32)$, mainly as a result of similar disease incidences (Santschi et al., 2011b). Loss of milk production due to antibiotic residues was not considered in the costs of metabolic disorders, included under veterinary services. However, because individual test-day milk yields were used to generate lactation curves (reported in Santschi et al., 2011a), the negative effects that metabolic disorders can have on the subsequent lactation were accounted for. The cost of the use of SNAP Beta-Lactam Tests for antibiotic testing for cows that had less than $28 \mathrm{~d}$ dry was included.

The culling rate was measured in the herds, and was assumed to be equal to replacement rate: the number of heifers required on a yearly basis was equal to the number of cows leaving the herd. Additionally, it was assumed that $50 \%$ of calves were females and that mortality rate was $5 \%$. Replacement costs included milk

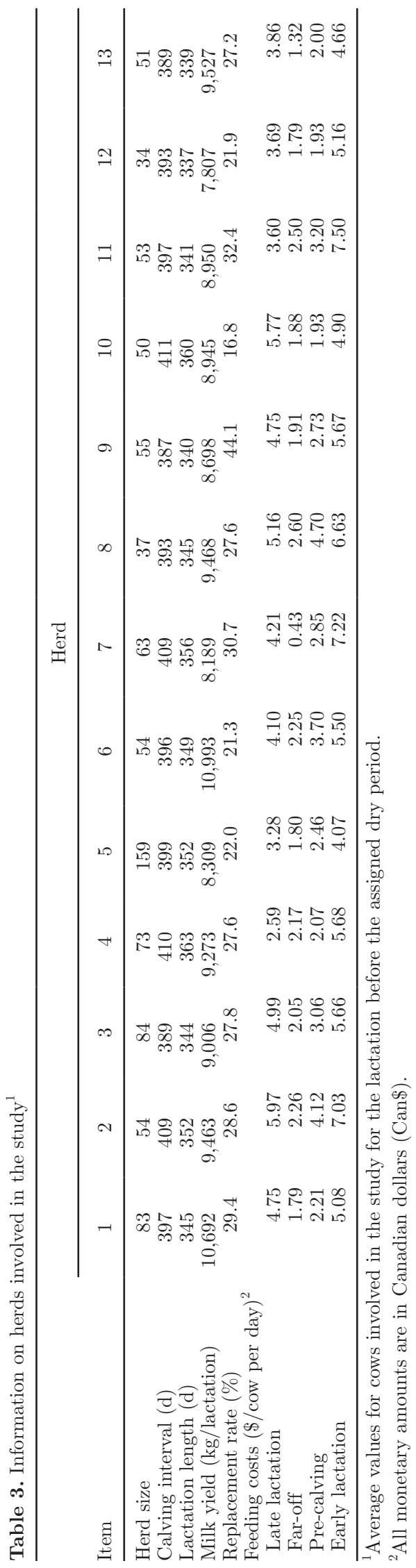


Table 4. Economic parameters according to dry period management strategy

\begin{tabular}{|c|c|c|c|c|}
\hline Item & $\mathrm{SDP}^{1}$ & $\mathrm{CDP}^{2}$ & SE & $P$-value \\
\hline Number of cows & 422 & 428 & & \\
\hline Dry period length $(\mathrm{d})$ & 37.3 & 65.3 & 2.1 & $<0.001$ \\
\hline Calving interval $(\mathrm{d})$ & 387.4 & 406.1 & 4.1 & $<0.001$ \\
\hline Breeding (per cow per year) & 2.1 & 2.1 & 0.1 & 0.82 \\
\hline \multicolumn{5}{|l|}{ Production $(\mathrm{kg} /$ cow per year $)$} \\
\hline Milk & 9,823 & 9,254 & 257 & 0.002 \\
\hline Fat & 386.2 & 359.0 & 11.8 & $<0.001$ \\
\hline Protein & 330.4 & 307.8 & 8.8 & $<0.001$ \\
\hline Lactose + other solids & 546.2 & 514.2 & 15.2 & 0.002 \\
\hline Veterinary services $(\$ / \text { cow per year })^{3}$ & 22.4 & 21.1 & 1.6 & 0.31 \\
\hline Replacement $(\%)^{4}$ & 26.1 & 28.9 & 2.3 & 0.37 \\
\hline \multicolumn{5}{|l|}{ Feeding costs $(\$ / \text { cow per year })^{3}$} \\
\hline Additional DIM $^{5}$ & 114.91 & - & 7.14 & - \\
\hline Far-off & - & 75.06 & 4.58 & — \\
\hline Pre-calving & 100.80 & 54.08 & 8.10 & $<0.001$ \\
\hline Early lactation & 872.96 & 831.76 & 50.40 & 0.005 \\
\hline Late lactation & 809.23 & 733.09 & 62.87 & $<0.001$ \\
\hline \multicolumn{5}{|l|}{ Housing (d/cow per year) } \\
\hline Additional DIM $^{5}$ & 26.5 & - & 1.3 & - \\
\hline Far-off & - & 39.7 & 1.3 & - \\
\hline Pre-calving & 35.1 & 19.0 & 1.1 & $<0.001$ \\
\hline Late lactation & 303.3 & 306.3 & 2.0 & 0.002 \\
\hline
\end{tabular}

${ }^{1}$ Short dry period, 35 d dry.

${ }^{2}$ Conventional dry period, $60 \mathrm{~d}$ dry.

${ }^{3}$ All monetary amounts are in Canadian dollars (Can\$).

${ }^{4}$ Assumed to be equivalent to the culling rate, which was reported elsewhere (Santschi et al., 2011b).

${ }^{5}$ Specifically during the additional DIM during which SDP cows are milked and CDP cows are dry.

and feeds consumed by the heifer, average veterinary and breeding expenses, as well as all other variable costs (bedding, registration). All male calves and heifers not required for replacement (exceeding the replacement rate) were assumed to be sold at $7 \mathrm{~d}$ of age. The replacement rate was similar for both DP management strategies $(P=0.37$; Table 4$)$.

Feeding costs were influenced by the DP management used $(P \leq 0.005)$. Conventional DP feeding typically includes a far-off ration, low in energy, from dry-off until $21 \mathrm{~d}$ before the expected calving date. Cows are then switched to a pre-calving ration, moderate in energy, until calving. Management for SDP implies that far-off ration is completely omitted and that cows are fed the late-lactation ration until being dried-off $35 \mathrm{~d}$ before calving. Cows are then fed the pre-calving ration for the whole duration of the DP. Far-off rations are usually based mainly on forages, which are less expensive than concentrates. Skipping the far-off ration, low in energy, and replacing it by a moderate-energy ration increases feeding costs for the producer. On average, yearly feeding costs were increased by approximately $\$ 200$ per cow with the SDP management strategy (considering variations in costs during the dry period as well as during lactation). Among the 13 herds, cows were fed the early lactation ration for an average of 160 $\mathrm{d}$ before being switched to the late lactation ration.
Housing costs were similar for dry or lactating cows in the present case because dry cows were kept in the same building as the lactating cows, except in the summertime when they sometimes had access to the outside. Accordingly, the number of days spent in specific stalls (lactating stalls or dry stalls) varied according to treatment (Table 4), but because cost per stall was the same, no differences existed in total annual costs per cow.

Labor costs were difficult to estimate due to the small number of herds and the lack of precision in the estimate made by the producers regarding the time spent for each activity related to the cows (milking, feeding, treatment administration). Because it was not possible to be on-farm and take precise measures regarding labor, this aspect of the economic impact must be excluded from calculations. It is likely that SDP management will require more milking time per cow per year, due to the additional days in milk at the end of lactation. However, the fact that 1 ration is omitted in the DP might result in time saved for ration preparation. This is especially true for large dairies. Besides milking and ration preparation time, labor time should be similar for both management strategies: cows need to be milked and fed daily no matter to which treatment they are assigned. During the DP, feeding a far-off or pre-calving ration to the cow yields negligible labor 
differences. Because disease incidences were similar for both groups, the labor required for treatment administration should also be equivalent.

\section{Partial Budget}

Economic variables described above and presented in Table 4 were used to calculate the partial budget comparing SDP and CDP management strategies on a herd basis. The approach presented in the current project used actual means by treatment to compute the economic calculations, although these means were not always different between treatments. The purpose of doing the analysis this way was to compute the cumulative economic effect of this change in DP management, which best represents the actual economic impact for a producer.

In Canada, the amount of milk sold daily per herd is limited by the amount of quota owned by the farm. For calculation purposes, we set the amount of quota owned by the farm to $68.5 \mathrm{~kg} \mathrm{BF} / \mathrm{d}$, which represents the average quota owned by the 13 herds involved in the present study. As reported in Table 4, SDP management increased the yearly fat yield per cow, suggesting that fewer cows will be required to produce the same quota, or that additional quota will be needed to sell all of the milk produced. Both scenarios were analyzed, with average results from the 13 herds used for calculations.

Scenario 1: Quota Kept Constant. Assuming that the amount of quota owned is kept constant implies that cows must be sold to avoid over-quota milk production. In the present case, 70 cows were needed with the CDP management to produce the daily $\mathrm{BF}$ allowed, whereas 65 cows were required with the SDP management. Consequently, this partial budget was calculated assuming that 5 fewer cows were present in the herd. All values for this partial budget are reported in Table 5, with results presented as SDP minus CDP.

In this scenario, the SDP management strategy decreased income, mainly because of less revenue from animals sold $(-\$ 1,816)$ : fewer calves were sold due to the decreased herd size, and fewer cows were culled due to the decreased replacement rate associated with SDP and to the decreased number of cows. In addition, revenues from milk sold were inferior with the SDP management: although the quantity of BF sold was equal, switching to an SDP management strategy resulted in the herd selling 9,362 $\mathrm{kg}$ less milk, $29 \mathrm{~kg}$ less protein, and $503 \mathrm{~kg}$ less lactose and other solids on a yearly basis. Selling less protein, lactose, and other solids decreased revenues because producers are paid based on component yields. However, this also lowered milk marketing costs (based on kilograms of solids sold). Moreover, due to the fact that less milk volume was produced, there were also savings on transportation costs. The cumulative net loss for switching to an SDP management was $\$ 777$.

Replacement costs were decreased considerably in this partial budget, due to the lower number of animals in the herd and the slightly decreased replacement rate with SDP. Housing costs, as well as reproduction and other variable costs, were decreased as a result of the smaller herd size. Feeding costs increased by $\$ 4,426$ because the late-lactation and pre-calving rations are more expensive than the far-off ration, which is omitted in the SDP management. On a daily cow basis, the average costs of the rations were: $\$ 1.90$ for the far-off ration; $\$ 2.84$ for the pre-calving ration; $\$ 5.75$ for the early lactation ration; and $\$ 4.47$ for the late-lactation ration. On average, cows spent $161 \mathrm{~d}$ eating the early lactation ration (range: 100 to $200 \mathrm{~d}$, depending on herd). Accordingly, on a herd basis, switching to an SDP management increases feeding costs by approximately $\$ 7,500$ and $\$ 2,700$ for end-of-lactation and precalving rations, respectively, whereas $\$ 5,300$ are saved on far-off ration. Although specific ration costs were

Table 5. Partial budget with scenario 1 (quota kept constant) ${ }^{1}$

\begin{tabular}{lc}
\hline Item & $\$ / \mathrm{yr}^{2}$ \\
\hline Variation in income $^{3}$ & -777 \\
Milk sold $^{3}$ & $-1,816$ \\
Animals sold $^{4}$ & $-2,593$ \\
Total & $-5,871$ \\
Variation in costs $^{\text {Replacement }}{ }^{5}$ & -638 \\
Reproduction $_{\text {Treatments and veterinary services }}$ & 3 \\
Feeding & 4,426 \\
Housing & $-1,235$ \\
Other variable costs & $-1,955$ \\
Total & $-5,270$ \\
Variation in net income & 2,677 \\
Per cow & 41.38 \\
\hline
\end{tabular}

${ }^{1}$ Calculations are based on available quota set to $68.5 \mathrm{~kg}$ of butterfat $(\mathrm{BF}) / \mathrm{d}$. The number of cows required to produce this amount of BF is 70 on conventional dry period management (CDP; $60 \mathrm{~d}$ dry) and 65 on short dry period management (SDP; $35 \mathrm{~d}$ dry). Calculations imply that 5 cows are sold.

${ }^{2}$ Amounts are expressed as SDP - CDP. All amounts are in Canadian dollars (Can\$).

${ }^{3}$ On a herd basis and considering the lower number of animals on SDP, yearly protein and lactose production were decreased by approximately 29 and $503 \mathrm{~kg}$, respectively, which decreased revenues from milk sold.

${ }^{4}$ Estimated as the price obtained for culled cows $(\$ 319 /$ cow $)+$ price obtained for any calves not required for replacement, which are assumed to be sold at $7 \mathrm{~d}$ of age ( $\$ 150 /$ male calf, $\$ 250 /$ female calf). The 5 cows originally sold in this scenario are not part of the calculation.

${ }^{5}$ Estimated as [(number of cows SDP $\times$ replacement rate SDP) (number of cows $\mathrm{CDP} \times$ replacement rate $\mathrm{CDP})] \times$ replacement cost $/$ heifer.

${ }^{6}$ Determined as the cost per stall $\times$ number of stalls occupied (number of cows). Cost per stall was estimated to be $\$ 290.63 / \mathrm{m}^{2}$ (Table 1 ). 
variable among herds, the average difference for the 2 management strategies was approximately $\$ 200$ per cow per year, as mentioned previously.

Overall, for an average herd of 70 cows (representing the average of the 13 herds involved in the present study), switching from a conventional to a short DP management would allow the producer to decrease the size of the herd by 5 cows while maintaining BF production and would result in $\$ 2,677$ of additional net annual income, which corresponds to approximately $\$ 41 /$ cow per year.

Scenario 2: Number of Cows Kept Constant. Producers might also decide not to decrease the size of their herds to maximize stall occupancy in their facilities and rather increase herd milk production. As mentioned previously, the Canadian dairy industry operates under a supply management system. To increase herd milk production and sell additional milk, producers must therefore consider buying additional quota. According to the present results, if all 70 cows are kept in the herd, $74.0 \mathrm{~kg}$ of quota would be required, implying that the producer would have to buy $5.5 \mathrm{~kg}$ of quota. Top quota price in the province of Quebec was set to $\$ 25,000 / \mathrm{kg}$ of $\mathrm{BF}$ in 2008 , and this value was, therefore, used for calculations. Results for this scenario are presented in Table 6. Again, values for this partial budget are presented as SDP minus CDP.

Additional yearly component yields per cow with an SDP management increased herd income from milk sold by almost $\$ 35,000$ (Table 6 ). Revenues from animals sold were slightly decreased because of the slightly lower culling rate observed with SDP, therefore decreasing income from culled cows. The lower replacement rate also increased revenues from calves sold, but to a lesser extent.

Annual changes in reproduction (\$13) and veterinary costs (\$122) were negligible. Increased costs associated with SDP were mainly attributed to increased feeding costs $(\$ 14,192$; Table 6$)$. As explained previously, this is the result of the low-cost far-off ration being replaced by more expensive late-lactation and pre-calving rations during the DP. Another element that must be considered in the present scenario is the interest on the quota bought. For calculation purposes, we assumed that the quota was bought at $\$ 25,000 / \mathrm{kg}$ of $\mathrm{BF}$ and financed for $10 \mathrm{yr}$ at $8.0 \%$ interest rate. The yearly interest payment was calculated using the PMT function in Excel software (Microsoft Corp., Redmond, WA). This function calculates the payment for a loan based on constant payments and a constant interest rate. Because quota value does not decrease over time, no depreciation was considered.

In this situation, additional net income would be $\$ 17,132$ for an average 70 -cow herd switching from
Table 6. Partial budget with scenario 2 (number of cows kept constant $)^{1}$

\begin{tabular}{lc}
\hline Item & $\$ / \mathrm{yr}^{2}$ \\
\hline Variation in income & \\
Milk sold & 34,799 \\
Animals sold & \\
Total & -137 \\
Variation in costs $^{3}$ & 34,662 \\
Replacement $^{4}$ & $-3,499$ \\
Reproduction $^{\text {Treatments and veterinary services }}$ & 13 \\
Feeding & 122 \\
Interest on quota $^{5}$ & 14,192 \\
Total & 6,702 \\
Variation in net income & 17,530 \\
Per cow & 17,132 \\
\hline
\end{tabular}

${ }^{1}$ Calculations are based on a herd of 70 cows. Available quota required to sell all milk produced is $68.5 \mathrm{~kg}$ of butterfat $(\mathrm{BF}) / \mathrm{d}$ on conventional dry period management (CDP; $60 \mathrm{~d}$ dry) and $74.0 \mathrm{~kg}$ of $\mathrm{BF} / \mathrm{d}$ on short dry period management (SDP; 35 d dry). Calculations imply that 5.5 $\mathrm{kg}$ of quota are bought.

${ }^{2}$ Amounts are expressed as SDP - CDP. All amounts are in Canadian dollars (Can\$).

${ }^{3}$ Estimated as the price obtained for culled cows $(\$ 319 /$ cow $)+$ price obtained for any calves not required for replacement, which are assumed to be sold at $7 \mathrm{~d}$ of age ( $\$ 150 /$ male calf, $\$ 250 /$ female calf).

${ }^{4}$ Estimated as number of cows in herd $\times(\mathrm{SDP}$ replacement rate $\mathrm{CDP}$ replacement rate) $\times$ replacement cost $/$ heifer.

${ }^{5}$ Assuming $5.5 \mathrm{~kg}$ of quota are bought at $\$ 25,000 / \mathrm{kg}$ and financed at $8.0 \%$ over $10 \mathrm{yr}$.

CDP to SDP management and purchasing quota, which corresponds to approximately $\$ 245 /$ cow. Impacts on the cash flow were also calculated. According to the previous assumptions on quota interest, annual quota payments would be $\$ 20,372$ (including interest) and cash flow variation would, therefore, be $\$ 3,462$. Accordingly, even when considering the annual payments on the quota bought during the $10 \mathrm{yr}$ of financing, this scenario would still be profitable. Cash flow variation after these $10 \mathrm{yr}$ of interest payments would be increased by $\$ 23,833$ with SDP.

Comparison Between the 2 Scenarios. In both scenarios, switching to a short DP would yield net benefits per cow on a yearly basis for an average eastern Canadian herd. Although scenario 2 is much more profitable, it might not always be possible. In the Canadian context, quota is limited to ensure milk price and it is, therefore, not always possible to buy additional quota. Under these circumstances, it would be preferable to decrease herd size (scenario 1) to lower labor and feed costs rather than to produce unpaid milk. Labor time saved in this scenario could temporarily be re-allocated elsewhere, until quota becomes available. In a situation where additional quota can be obtained, scenario 2 shows that the additional revenue would be worth the investment. 


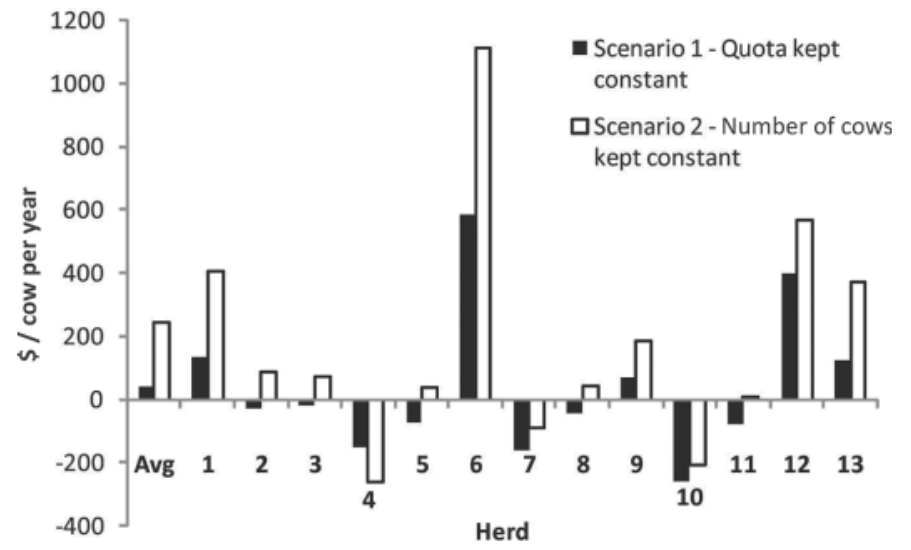

Figure 1. Variation in net income per cow per year for an average herd (Avg) and among the 13 herds involved in the study. Results are reported as the difference between short (35-d) and conventional (60d) dry period management, expressed in Canadian dollars. Scenario 1 considered the amount of available quota as constant and, therefore, implies that cows are sold to avoid over-quota production. Scenario 2 assumes all cows are kept in the herd and estimates net income following the purchase of extra quota. The respective number of cows involved in the study per herd was $1=83 ; 2=54 ; 3=84 ; 4=73$; $5=159 ; 6=54 ; 7=63 ; 8=38 ; 9=54 ; 10=50 ; 11=53 ; 12=34$; and $13=51$

Sørensen et al. (1993) evaluated results from their stochastic simulation model under both herd size and milk quota constraints, expressing results in terms of Danish krone/cow per year and Danish krone/tonne of milk sold, respectively. According to Sørensen et al. (1993), the net revenue per unit of milk sold was less sensitive to dry period length than was the net revenue per cow per year.

Variation Among Herds. Partial budgets for both scenarios were variable among herds (Figure 1). To allow comparison of farms of different sizes, all values were reported as yearly benefit or loss on a cow basis.

For most herds, both scenarios followed the same trend. Results could not be linked to herd size (number of cows per herd reported in Figure 1). According to previously published results (Santschi et al., 2011a,b), net income variation can be attributed to overall effects obtained by each herd following an SDP management strategy. From the combination of these results, it can be observed that the effect of SDP management on milk and component yields plays an important role in the variation in net income. Santschi et al., (2011a,b) reported higher total lactation ECM yields for SDP cows compared with CDP cows, for all herds except herd number 4 , in which SDP management yielded a loss in net income. On the other hand, herd numbers 6,12 , and 13 were the herds with the highest increase in ECM yield (Santschi et al., 2011a). In the present study, these same farms are the ones with the highest gain in net income. Herd number 10 had higher-than- average ration costs for the end of lactation ration: $\$ 1.52$ cow per day above the average of the 12 other herds. Although not the only reason, this increased cost contributed to the loss of net income.

In the study by Sørensen et al. (1993), the authors mention that ranking of the different dry period lengths tested $(4,5,6,7,8,9$, and $10 \mathrm{wk})$ seemed quite insensitive to management strategy. It is important to note that these authors only simulated 4 management strategies, namely high- or low-concentrate feeding (12 or $8 \mathrm{~kg} / \mathrm{d}$ ) and high or low culling rate (maximum days open set at 210 and 168 DIM for high- and lowproducing cows under high culling rate strategy, and 315 and 273 DIM for high- and low-producing cows under low culling rate strategy, respectively). The authors concluded that it was likely that improved management strategies would not change these conclusions. However, these authors did not consider variations in several other aspects, such as disease incidence, replacement costs, and conception rate, which should be considered when evaluating the overall economic effect of modifying the dry period management strategy. In addition, their conclusions were based on a simulation model rather than on field results influenced by the producers' management decisions. Results from the present study demonstrate that SDP management might be very profitable to some herds, which contradicts the conclusions of Sørensen et al. (1993). Further analyses are required to identify management or herd parameters that explain this between-herd variation.

\section{CONCLUSIONS}

Short (35-d) DP management has been reported to bring interesting beneficial effects, namely additional milk at the end of lactation and improved health and reproductive performance. This study measured the economic impact of this new practice. In a context specific to the Canadian dairy industry as investigated here, results indicate that an average herd would benefit from switching from a conventional to a short DP management system. Although feeding costs greatly increase with short DP management, the benefits from additional milk sold and decreased replacement rate overcome the feeding investment. Our calculations indicate that an average 70-cow herd could either sell 5 cows (scenario 1) or buy an additional $5.5 \mathrm{~kg}$ of quota (scenario 2) to sell all milk produced. Considering each scenario individually, yearly benefits would be $\$ 41.38$ or $\$ 245.18$ per cow for scenarios 1 and 2, respectively. A more precise estimate of labor variation between both management practices would provide additional information useful to producers making management decisions. Net income variation expressed on a per-cow 
basis was variable among herds, mainly as a result of production response to shorter DP. These calculations could be adapted to specific conditions in various regions and countries. Finally, the partial budgets presented here may be used to estimate the economic impact of this novel management practice. Economic considerations will be important in decision making at the herd level.

\section{ACKNOWLEDGMENTS}

The authors acknowledge the invaluable contribution of the producers, veterinarians, and nutritionists involved in this study for their participation. Special thanks to Vincent Caldwell and Virginie Filteau (Clinique Vétérinaire de Coaticook, Quebec, Canada) as well as Pierre-Luc Charbonneau (Bureau Vétérinaire de Richmond, Quebec, Canada) for their help in estimating costs of metabolic disorders. This project was financed by the Action Concertée Novalait-FQRNTMAPAQ-AAC (Quebec, QC, Canada).

\section{REFERENCES}

Annen, E. L., R. J. Collier, M. A. McGuire, J. L. Vicini, J. M. Ballam, and M. J. Lormore. 2004. Effect of modified dry period lengths and bovine somatotropin on yield and composition of milk from dairy cows. J. Dairy Sci. 87:3746-3761.

Canadian Dairy Commission. 2010. Canadian Dairy Commission. Accessed Feb. 16, 2010. www.cdc-ccl.gc.ca.

Capuco, A. V., R. M. Akers, and J. J. Smith. 1997. Mammary growth in Holstein cows during the dry period: Quantification of nucleic acids and histology. J. Dairy Sci. 80:477-487.

CRAAQ (Centre de Référence en Agriculture et Agroalimentaire du Québec). 2005. Entreprise laitière. Analyse comparative taille d'entreprise 2003. Analyse de données AGRITEL. AGDEX 412.11/890. Références économiques.

CRAAQ (Centre de Référence en Agriculture et Agroalimentaire du Québec). 2008. Étable pour bovins laitiers et laiterie. Coûts de construction. AGDEX 722/410. Références économiques.
Jolicoeur, M. S., A. F. Brito, D. Pellerin, D. Lefebvre, R. Berthiaume, and C. L. Girard. 2009. Short dry period management improves peripartum ruminal adaptation in dairy cows. J. Dairy Sci. 92(Suppl. 1):333.

Klusmeyer, T. H., A. C. Fitzgerald, A. C. Fabellar, J. M. Ballam, R. A. Cady, and J. L. Vicini. 2009. Effect of recombinant bovine somatotropin and a shortened or no dry period on the performance of lactating dairy cows. J. Dairy Sci. 92:5503-5511.

Pezeshki, A., J. Mehrzad, G. R. Ghorbani, H. R. Rahmani, R. J. Collier, and C. Burvenich. 2007. Effects of short dry periods on performance and metabolic status in Holstein dairy cows. J. Dairy Sci. 90:5531-5541.

Rastani, R. R., R. R. Grummer, S. J. Bertics, A. Gümen, M. C. Wiltbank, D. G. Mashek, and M. C. Schwab. 2005. Reducing dry period length to simplify feeding transition cows: milk production, energy balance, and metabolic profiles. J. Dairy Sci. 88:1004-1014.

Santschi, D. E., D. M. Lefebvre, R. I. Cue, C. L. Girard, and D. Pellerin. 2011a. Complete-lactation milk and component yields following a short (35-d) or conventional (60-d) dry period management in commercial Holstein herds. J. Dairy Sci. 94:2302-2311.

Santschi, D. E., D. M. Lefebvre, R. I. Cue, C. L. Girard, and D. Pellerin. 2011b. Incidence of metabolic disorders and reproductive performance following a short (35-d) or conventional (60-d) dry period management in commercial Holstein herds. J. Dairy Sci. doi:10.3168/jds.2010-3595.

SAS Institute. 2008. User's Guide: Statistics. Version 9.2 ed. SAS Institute Inc., Cary, NC.

Sørensen, J. T., and C. Enevoldsen. 1991. Effect of dry period length on milk production in subsequent lactation. J. Dairy Sci. $74: 1277-1283$.

Sørensen, J. T., C. Enevoldsen, and T. Kristensen. 1993. Effects of different dry period lengths on production and economy in the dairy herd estimated by stochastic simulation. Livest. Prod. Sci. $33: 77-90$.

Valacta. 2009. Évolution de la production laitière québécoise 2008. Pages 33-62 in Le Producteur de Lait Québécois. Numéro spécial.

Watters, R. D., J. N. Guenther, A. E. Brickner, R. R. Rastani, P. M. Crump, P. W. Clark, and R. R. Grummer. 2008. Effects of dry period length on milk production and health of dairy cattle. J. Dairy Sci. 91:2595-2603.

Watters, R. D., M. C. Wiltbank, J. N. Guenther, A. E. Brickner, R. R. Rastani, P. M. Fricke, and R. R. Grummer. 2009. Effect of dry period length on reproduction during the subsequent lactation. J. Dairy Sci. 92:3081-3090. 